\title{
Plight of US postdocs... in the US
}

Sir — The Aaron Diamond Aids Research Center in New York has only a few students, as it is primarily a research institute. But we have many young postdocs. My own lab consists of me (British), six postdocs (one each from Britain, Serbia, China, India and two from Austria), one student (American) and several American technicians.

It is immediately obvious which nationality is missing from the senior lineup. Of the two US postdocs I have had, one left after three years for a position in scientific administration with greater perceived job security, the other quit after a year to move to industry and was paid more for less intense work. I have been trying to recruit another American who has just completed his $\mathrm{PhD}$ at a top university. Our institution is his first choice academically, but he prefers to move to industry "because it pays more".

When smart students could go on to make fortunes in US society as lawyers, investors, bankers and so on, how can science compete? All it has going for it is the noble but nebulous "vocational" aspect that only a minority of students ever feel.

The NIH official stipend for a new postdoc is $\$ 21,000$; for students it is a mere $\$ 11,748$. In the United States, a PhD in biological sciences is rarely awarded before the age of 30, so smart students spend their 20s earning a pittance compared to their excolleagues in other fields. Then they may easily fail to find a full-time academic position, while still having student loans to pay off. Is it any wonder, given the nature of US society, that fewer and fewer young people want to enter science (see Nature 395, 101; 1998)? As one of our students put it to me: "when my lawyer friends want to go to a pricey restaurant or I have to spend another sleepless night rushing around the lab, I figure the effort to reward ratio is a bit skewed in science. It's worth it, but sometimes I wonder." The most committed students stick it out regardless, but it is not made easy for them, given alternative temptations.

For foreigners, especially nonEuropeans but even including Europeans, US scientific salaries are very attractive by the standards in their own countries. If it weren't for foreign imports at the postdoc level, the US science structure would rapidly disintegrate. Some countries use the United States to train their brightest young people so that they can create a native scientific infrastructure if and when they finally return: first Japan, then Korea, now China and, to a lesser extent, India.

Excluding immigrants is not the answer, unless the United States is willing to minimize its scientific output for several years while it trains home-bred replacements (assuming it could).

In reality, if more young people in the United States are to study science professionally, the government will have to pay them more. Perhaps instead of spending \$40 million on the Starr report, the money could have been used to train more young scientists how to, for example, analyse DNA samples.

\section{John Moore}

Aaron Diamond AIDS Research Center,

New York, New York 10016, USA

e-mail:jmoore@adarc.org

\section{Hope or hype for lexipafant?}

Sir - I read the News article on the large multicentre trial of lexipafant (Zacutex) in severe pancreatitis and the response of the chief executive of British Biotechnology (Nature 393, 291, 299 \& 509; 1998). I used lexipafant to block platelet-activating factor in different models of shock and sepsis during 1993-95 at Linköping University, Sweden. It was hard to defend my $\mathrm{PhD}$ thesis because of the lack of published data on the basic pharmacology of lexipafant at that time. I am disappointed that this remains the case despite progress in clinical trials.

Commercial considerations resulting from the potential for profit from a new treatment in areas where there is a high rate of death, like severe pancreatitis, are no excuse for keep this basic pharmacological data hidden.

I searched three major medical databases and found that 37 peer-reviewed scientific papers related to lexipafant have been published. Fourteen were review articles and five were original experimental papers on acute pancreatitis, which did not collectively show clear evidence for improved survival (via an antiinflammatory effect) for those taking this drug. Yet only two of the review articles were conservative about the future of lexipafant whereas most, including mine, were hopeful.

Scientific literacy in the investment community is of no use without an appreciation of the difference between hope and facts - I will not be surprised if the large multicentre trial of lexipafant in the United States fails, but I hope it will not.

I wonder how much it will cost to acknowledge that the inflammatory process cannot be hit by a single golden bullet. The line between hope and hype is a thin one, and in this case it is only when the results of large-scale trials are available that it will be clear where it should be drawn.

\section{Fikri M. Abu-Zidan}

Department of Surgery, Auckland Hospital, Faculty of Medicine and Health Science, University of Auckland, Park Road, Auckland, New Zealand

e-mail:f.abu-zidan@auckland.ac.nz

\section{Animals at the Salk}

Sir - I would like to comment on the News item "Salk Institute investigated after claims of inhumane research" (Nature 394, 709; 1998). Since this matter is still in litigation, I will not address the specific allegations presented in the article. It is important to note, however, that most of these allegations are part of a continuing civil lawsuit brought by a former Salk employee who was dismissed for cause. They are not fact and should not be treated as fact.

That said, the first paragraph of your article omits the word "alleged" when describing "past inhumane treatment and faulty experiments" at Salk, while the term "exposed" is also argumentative. Other statements in the article do not accurately represent testimony or court record, or are presented without appropriate caveats. You state that our faculty was divided on the plaintiff's performance, but neglect to inform the reader that only one of 55 supported her and testified on her behalf.

The Salk Institute welcomes an investigation of our animal research department by responsible outside agencies, including the US Department of Agriculture and the NIH. We have run, and continue to run, a first-rate facility that meets all federal guidelines for the humane use of animals in research.

Not only is it in the animals' best interest that we operate in this manner, it is in our own best interests as well. We cannot conduct the kind of research with which we've been entrusted unless our labs and animal facilities are a match for the outstanding scientists we have assembled here.

Thomas D. Pollard

(President)

The Salk Institute for Biological Studies,

Post Office Box 85800

San Diego, California 92186-5800, USA 